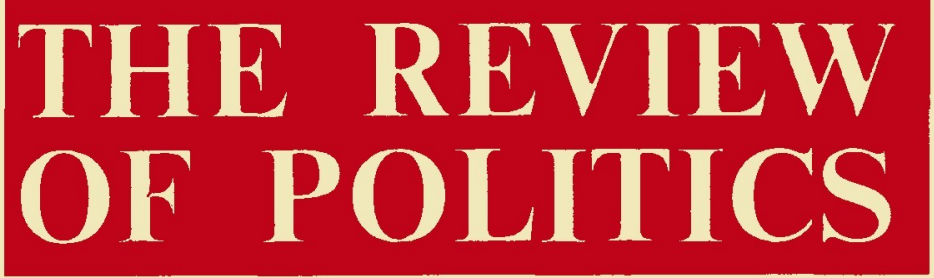

\title{
FORTIETH ANNIVERSARY
}

After Forty Years

Thomas Stritele

Voltaire: History Unexemplary M. A. Fitzsimons

Hungary 1948-1947

Stephen D. Kertesz

Maritain's Philosophy of Edueation Leo R. Ward

The Totalitarian State

\section{Waldemar Gurian}

Review Article

Philip Gleason: Greeley Watehing

Vol. $40 \cdot$ October, $1978 \cdot$ No. 4

University of Notre Dame

Nolre Dame, Indiana 


\title{
THE REVIEW DF PDLITICS
}

\author{
FredDerICK J. CROSSON \\ Editor
}

DENNIS Wm MORAN

Assistant Editor

M. A. FITYSIMONS

STEPHEN KERTESZ

Advisory Editors

\section{WALDEMAR GURIAN \\ M. A. FITZSIMONS}

Former Editors

Copyright 1978 by the University of Notre Dame. Published quarterly at the University of Notre Dame. Issued each January, April, July and October. Entered as second-class matter April 1, 1939, at the post office at Notre Dame, Indiana, under act of March 2,1879. Subscriptions: $\$ 10.00$ the year in the United States; foreign $\$ 11.00$; single copies $\$ 3.00$. 


\section{THE REVIEW OF POLITICS}

Published Quarterly by the University of Notre Dame, Indiana

\begin{tabular}{lll}
\hline Vol. 40 & October 1978 & No. 4 \\
\hline
\end{tabular}

Foreword

Thomas Stritch

AFTER FORTY YEARS: Notre Dame and The

Review of Politics

M. A. Fitzsimons

Voltaire: History Unexemplary and en Philosophe ....

Stephen D. Kertesz

Peacemaking on the Dark Side of the Moon:

Hungary 1943-47

LEO R. WARD

Maritain's Philosophy of Education for Freedom ......

Waldemar Gurian

The Totalitarian State

Review Article:

Philip Gleason: Greeley Watching 528

\section{Reviews:}

R. E. Burns: The Hill People ……...................................... 540

Eugene Davidson: Year Zero ................................................. 542

Gerhart Niemeyer: Violence: The Fruit of Modernity ............. 545

James Tunstead Burtchaell: Reheating the Mutton Chop of

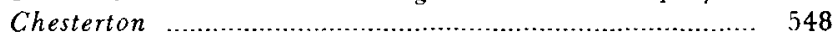

Donald J. Mattheisen: Ripples from the American Revolution .. 551

Bernard Norling: U.S. Intelligence and National Fairy Tales ... 553

Samuel Shapiro: Cuba before Castro ......................................... 558 


\section{Contributors to This Issue}

R. E. Burns, Associate Dean of Arts and Letters in the University of Notre Dame, is Associate Professor of History and a former member of a senator's staff. EUGENE DAVIDSON is author of The Making of Adolf Hitler (Macmillan, 1977). Gerhart NiEMEYer teaches government at the University of Notre Dame and Hillsdale College and is the author of "Freedom and Rights" in our April issue. James Tunstead Burtchaell, C.S.C., is Professor of Theology at Notre Dame and former Provost of the University. Donald J. Mattheisen teaches history at Lowell State College. Bernard Norling teaches in Notre Dame's History Department. Samuel Shapiro is Associate Professor of History at Notre Dame.

The Review of Politics, without neglecting the analysis of institutions and techniques, is primarily interested in the philosophical and historical approach to political realities.

The articles in The Review of Pourtics are indexed in the International Index to Periodicals and the Index of Catholic Periodicals and abstracted in the International Political Science Abstracts. They are abstracted and indexed in ABC POL. SCI. and HISTORICAL ABSTRACTS and Social Sciences Index. 